\title{
Amaranth irrigation frequency in northeast Patagonia, Argentina
}

\author{
Maria Fany Zubillaga ${ }^{(1)}$, Roberto Simón Martínez ${ }^{(1,2)}$, Ricardo Camina ${ }^{(3)}$, Gustavo \\ Adolfo Orioli ${ }^{(3,4)}$, Mauricio Failla ${ }^{(5)}$, Maite Alder ${ }^{(2)}$, Daniel Alejandro Barrio ${ }^{(1,4)}$ \\ (1) Universidad Nacional de Rio Negro. Centro de Investigaciones y Transferencia Río Negro (CIT Río Negro). Viedma. Río \\ Negro (Argentina). E-mail: mzubillaga@unrn.edu.ar \\ (2) Instituto Nacional de Tecnología Agropecuaria (INTA). Estación Experimental Valle Inferior. Viedma. Río Negro \\ (Argentina). \\ (3) Universidad Nacional del Sur. Bahía Blanca. Buenos Aires (Argentina). \\ (4) Consejo Nacional de Investigaciones Científicas y Técnicas (CONICET). Ciudad Autónoma de Buenos Aires. Buenos \\ Aires (Argentina). \\ (5) Proyecto Patagonia Noreste. Balneario El Cóndor. Río Negro (Argentina).
}

Received 18 August 2020, accepted 12 October 2021, available online 17 November 2021.

This article is distributed under the terms and conditions of the CC-BY License (http://creativecommons.org/licenses/by/4.0)

Introduction. The production potential of grain amaranth has recently been demonstrated in northeastern Patagonia, Argentina. This crop under irrigation and in a temperate semi-arid climate showed an adequate development of the plants in their different phenological stages with high economic performance.

Objectives. This study explored the response of Amaranthus cruentus cv Mexicano to different irrigation frequencies in the lower valley of Río Negro river, Patagonia, Argentina.

Method. The experimental design was of three blocks with randomized treatments (subplots), each one corresponding to a different irrigation frequency (FI). The first six irrigations were performed every 7 days for all the treatments, to ensure the establishment of the crop. Then the following treatments were applied: irrigation every 7 days (FI), every 14 days (FII), and every 21 days (FIII). The following biometric variables and their components were measured: height of plant, number of leaves, biomass and economic yield.

Results. The results suggest that the optimum irrigation frequency was FII (14 days), resulting in an adequate plant stand at panicle initiation and allows a proper development of plant with optimal biological and economical yields and the highest efficiency of water use $\left(4.02 \mathrm{~kg} \cdot \mathrm{m}^{-3}\right)$.

Conclusions. The contributions of this study demonstrated the production potential of A. cruentus crop in the lower valley of the Río Negro river under irrigation, representing the southernmost study on irrigation frequency made for this grain crop in the world. A management of irrigation water of 7 days for the establishment of the crop and then with a frequency of 14 days showed the highest yield and the best water use efficiency.

Keywords. Grain amaranth, deficit irrigation, biomass, economic yield, water use efficiency, phenology, protein.

\section{Fréquence d'irrigation de l'amarante dans le nord-est de la Patagonie, Argentine}

Introduction. Récemment, il a été démontré le potentiel de la culture d'amarante en Patagonie du Nord, en Argentine. Cette culture sous irrigation et en climat tempéré semi-aride a montré un développement adéquat des plantes dans leurs différents stades phénologiques avec des performances économiques élevées.

Objectifs. Cette étude a exploré la réponse de Amaranthus cruentus cv Mexicano à une fréquence différente d'irrigation dans la basse vallée de la rivière Río Negro, en Patagonie, en Argentine.

Méthode. Un modèle expérimental de trois blocs avec des traitements randomisés (sous-parcelles), chacun correspondant à différentes fréquences d'irrigation (FI), a été appliqué. Les six premières irrigations pour tous les traitements effectués tous les 7 jours eurent pour but d'assurer l'implantation de la culture. Ensuite, la FI a maintenu cette fréquence, la FII tous les 14 jours et FIII tous les 21 jours. Les variables biométriques suivantes et leurs composants ont été mésurés : hauteur de la plante, nombre de feuilles, biomasse et rendement économique. 
Résultats. Les résultats suggèrent que FII est la fréquence d'irrigation optimale. Cette fréquence d'irrigation génère un peuplement adéquat à l'initiation des panicules et permet un développement correct de la plante avec des rendements biologiques et économiques optimaux et la meilleure efficacité d'utilisation de l'eau $\left(4,02 \mathrm{~kg} \cdot \mathrm{m}^{-3}\right)$.

Conclusions. Cette étude a démontré le potentiel de culture de A. cruentus dans la basse vallée de la rivière Río Negro, représentant l'étude de la densité d'installation réalisée pour cette culture de céréales la plus australe au monde. Une gestion de l'eau d'irrigation de 7 jours pour la mise en place de la culture puis avec une fréquence de 14 jours a montré le rendement le plus élevé et la meilleure efficacité d'utilisation de l'eau.

Mots-clés. Graines d'amarante, irrigation déficitaire, biomes, rendement économique, efficacité d'utilisation de l'eau, phénologie, protéine.

\section{INTRODUCTION}

Amaranthus cruentus cv Mexicano belongs to the Amaranthaceae family and this cultivar develops adequately in the edaphoclimatic conditions of northern Patagonia, Argentina (Zubillaga, 2017; Zubillaga et al., 2019; Zubillaga et al., 2020). Cultivated grain amaranth has attracted attention as a human nutritional source because its seeds contain a high content of protein (15$18 \%$ ) and the amino acid composition is similar to the optimum balance required in the human diet (Correa et al., 1986; Cassini \& La Rocca, 2014; Alemayehu et al., 2015). The agronomic relevance of amaranth is related to its fast-growing ability, adaptation to poor soil, tolerance to heat and drought with no major disease problems (Barba de la Rosa et al., 2007; Robert et al., 2008; Alemayehu et al., 2015). These characteristics are associated with the wide distribution of the species in the America (more than 3,000 accessions in gene banks) and its great genetic variability (Jacobsen \& Mujica, 2003).

In Northeast Patagonia optimal growing conditions (sowing in early December, planting density of 143,000 plants.ha ${ }^{-1}$ at $0.7 \mathrm{~m}$ row spacing, nitrogen fertilization of $150 \mathrm{~kg} \mathrm{~N} \cdot \mathrm{ha}^{-1}$ and water availability) significantly increase its yield (Zubillaga, 2017; Zubillaga et al., 2019). The soil water deficit is a principal factor that limits amaranth growth, therefore studies on different fertility, density and irrigation regimes have been carried out (Neluheni et al., 2007; Fasinmirin et al., 2009; Masariramb et al., 2012; Solanki et al., 2016; Ogunlela \& Sadiku, 2017).

Amaranth is a multipurpose crop that can be used as a grain, as vegetable (if its leaves are consumed) or as animal feed. Amaranth flour stands out for its high nutritional value and for being gluten-free (Venskutonis \& Kraujalis, 2013; Alemayehu et al., 2015) used alone or in combination with others flours (Brommer \& Morgenstern, 1992; Alemayehu et al., 2015; Hoidal et al., 2019). Grain amaranth in Argentina is sold in health food stores in the form of flour, grain or puffed cereal.

In north Patagonia, Argentina, the information regarding this crop is still limited. In order to increase the grain production, it is necessary to know how irrigation frequency influences the biometric parameters associated with yield. Plant height, leaf area, number of leaves, biomass and yield, among other traits, are affected by irrigation frequency according to each species, cultivar and environment (Liu \& Stützel, 2004; Neluheni et al., 2007; Masariramb et al., 2012). Recently, the potential for amaranth cultivation in the extensive irrigated valleys of northeast Patagonia has been considered (Zubillaga, 2017; Zubillaga et al., 2019).

The aim of this study was to evaluate the effect of irrigation frequency on the biometric and production parameters in Amaranthus cruentus cv Mexicano, in the eastern valley of the Río Negro river, Patagonia, Argentina.

\section{MATERIALS AND METHODS}

\subsection{Study area}

The field experiments were conducted at the Instituto Nacional de Tecnología Agropecuaria, Experimental Agricultural Station in the lower valley of the river Negro (INTA-EEAVI) $\left(40^{\circ} 48^{\prime} \mathrm{S}, 63^{\circ} 05^{\prime} \mathrm{W}\right.$, elevation of $4 \mathrm{~m}$ ). This area, located in the province of Río Negro, Patagonia, Argentina, has an irrigation system covering 24,000 ha. The initial physicochemical characteristics of the upper $50 \mathrm{~cm}$ of the experimental loam soil were: $\mathrm{pH}$ (8.14); electrical conductivity $(0.44$ mmhos. $\left.\mathrm{cm}^{-1}\right)$; organic matter $(2.18 \%)$; total nitrogen $(0.19 \%)$; $\mathrm{N}-\mathrm{NO}_{3}$ (24.30 mg.kg-1); P (Olsen, $\left.13.50 \mathrm{mg} \cdot \mathrm{kg}^{-1}\right)$; $\mathrm{S}\left(14.4 \mathrm{mg} \cdot \mathrm{kg}^{-1}\right.$ as a $\left.\mathrm{SO}^{=}\right) ; \mathrm{Ca}\left(8.30 \mathrm{mg} \cdot \mathrm{kg}^{-1}\right) ; \mathrm{Mg}$ $\left(1.16 \mathrm{mg} \cdot \mathrm{kg}^{-1}\right)$; sodium-adsorption ratio $(1.84)$. The soil characterization was made by analysis of the soil, water and plant tissues in the INTA-EEAVI laboratory.

During the 2010-2011 and 2011-2012 production cycles, the behavior of the dry land crop was evaluated. During December (when amaranth germinates and becomes established) the rainfall in the region is generally scarce. Without any irrigation the volume of water was deficient for the crop and, consequently, only a few plants completed their cycle. In those years the rainfall did not exceed $20 \mathrm{~mm}$ and the same situation was repeated in the following years. The plots without 
irrigation showed more than $90 \%$ loss of plants (data not shown) due to the reduced availability of water during December, and those that survived under these conditions showed little development and a reduced grain yield. This crop requires adequate soil moisture during emergence and the early stages of development to achieve good crop establishment (Johnson \& Henderson, 2002; Reinaudi et al., 2011). The field experimental plot showed that amaranth is drought tolerant at later stages of growth (Kauffman \& Weber, 1990). Therefore, it was decided to apply irrigation weekly until 40-45 days after planting in order to avoid distortions in the trial due to the loss of plants in this stage, based on the results obtained in preliminary trials without application of irrigation (2010-2011 and 20112012). In this period the plants reached an approximate size of $35-40 \mathrm{~cm}$ and the crop was at the beginning of the phenological stage of panicle development. After the initial period, the treatments were applied according to the corresponding irrigation frequencies. This practice of irrigating during the initial stages of cultivation is commonly used in the cultivation of corn in the Río Negro valley (Martínez et al., 2012; Reinoso, 2014).

This study was carried out during the 20122013 and 2013-2014 production cycles. The precipitation, average monthly temperature, reference evapotranspiration (ETo) and crop evapotranspiration
(ETc) for those years can be seen in figure 1. The evapotranspiration of the crop was estimated as a function of the values of crop coefficient $(\mathrm{Kc})$ of A.cruentus found in the bibliography (Ufoegbune et al., 2016). The monthly Kc values were $0.6 ; 1.1 ; 1.0$; 0.6; 0.3 for December, January, February, March and April, respectively, and the meteorological data was from the INTA EEAVI weather station.

\subsection{Irrigation frequencies and experimental design}

The treatments screened consisted of three irrigation frequencies. The first six irrigations for all treatments (first phase) were performed every 7 days to ensure crop establishment. Then the following treatments were applied (second phase): irrigation every 7 days (FI), every 14 days (FII), and every 21 days (FIII).

The yield of different amaranth varieties (A.cruentus cv Mexicano, A.caudatus cv Dorado, A.hypochondriacus cv Antorcha) were evaluated in Patagonia, Argentina. The results showed that the cultivar Mexicano was the one with the best yield (over 3,500 kg.ha-1) and health (Zubillaga, 2017). On the basis of these results, the variety of amaranth that best adapted was A.cruentus cv Mexicano used in this study. The sowing was done by hand in a straight line at the end of spring (December ${ }^{1 \mathrm{st}}$ ). Following Zubillaga (2017), weeding and thinning-out of the
2012-2013

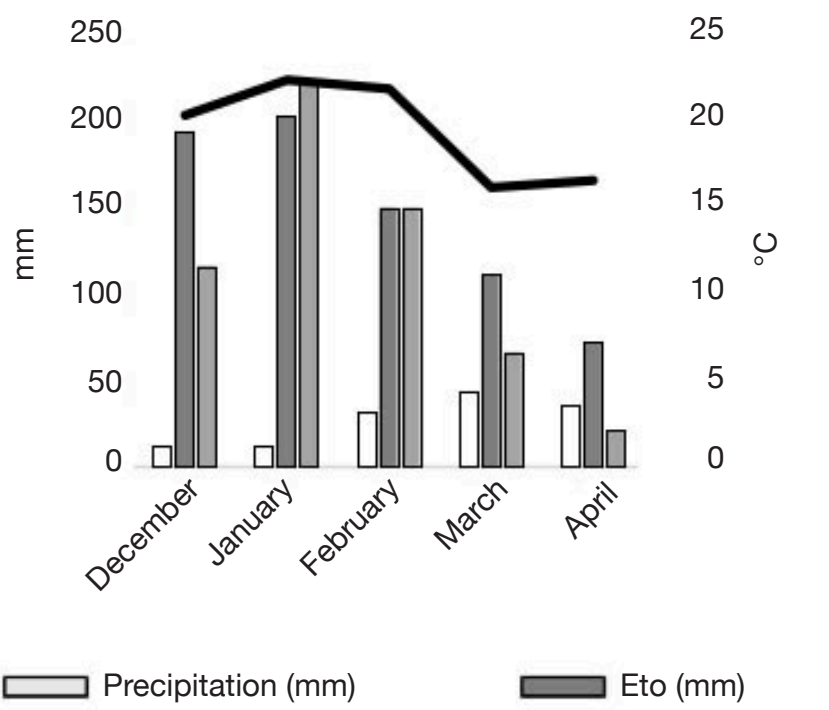

2013-2014

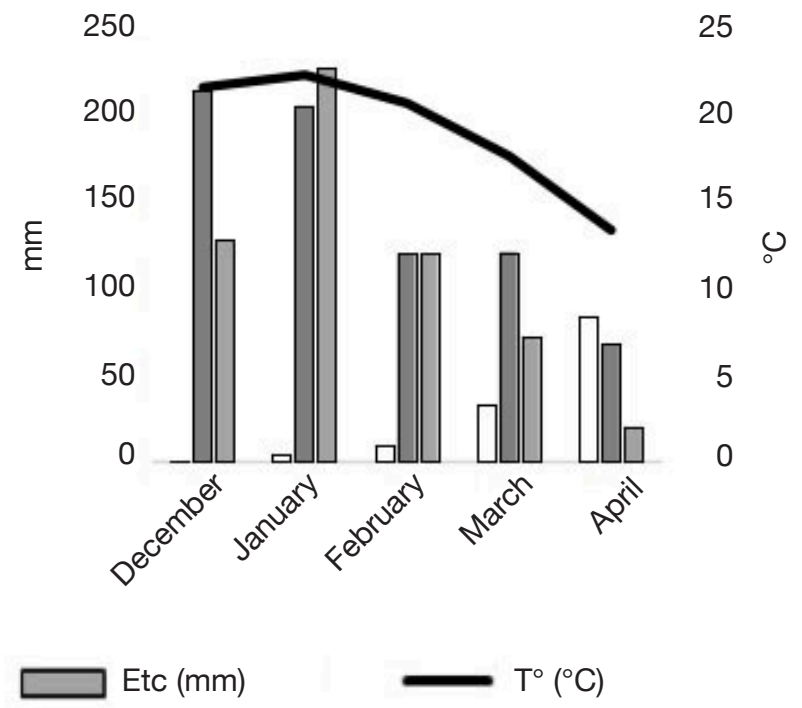

Figure 1. Average monthly precipitation, reference evapotranspiration (Eto), crop evapotranspiration (Etc) and temperature $\left(\mathrm{T}^{\circ}\right)$ during the crop production cycle. In the study years they were recorded daily despite the climatic data and they are shown as average values per month - Précipitations mensuelles moyennes, évapotranspiration de référence (Eto), évapotranspiration des cultures (Etc) et température $\left(T^{\circ}\right)$ pendant le cycle de production des cultures. Dans les années d'étude, ils ont été enregistrés quotidiennement malgré les données climatiques et sont indiqués en valeurs moyennes par mois. 
crops was performed manually when the plants reached a height of $20-30 \mathrm{~cm}$, in order to get a plant density of 15 plants $\mathrm{m}^{-2}$. Nitrogen fertilization was of $150 \mathrm{~kg} \mathrm{~N} \cdot \mathrm{ha}^{-1}$, each fertilization treatment was divided into two doses: half when plants had grown to a height of $60 \mathrm{~cm}$, and the second half at the beginning of the inflorescence stage.

The experimental design was three blocks with three treatments of irrigation frequency randomly distributed within each block. The surface area of each sub-plot was $21.00 \mathrm{~m}^{2}$ (five furrows $0.70 \mathrm{~cm}$ wide $\mathrm{x}$ $5 \mathrm{~m}$ long).The irrigation was performed by gravitation with a flow rate $(\mathrm{Q})$ of $1.6 \mathrm{~L} \cdot \mathrm{s}^{-1}$ per furrow, determined by the soil field capacity and root depth. The flow was calculated at a fixed time and the average time $(\mathrm{t})$ was $4 \mathrm{~min}$, enough to cover the irrigation of the entire surface of the experimental plot for all treatments. The sheet of water applied to the plots was calculated from the flow used and the time of irrigation (Fuentes Yague, 1998).

Different samples of soil were taken from the experimental site in order to determine the values of permanent wilting point (WP) and field capacity (FC). The analyses were carried out in the Laboratory of Conservation and Management of Soil - Department of Agronomy of the Universidad Nacional del Sur. The determinations were made using the methodology of Richards (1947) and Klute (1986) with the following results: FC: 43.8\%; WP: 19.4\%; AWC (available water content: FC - WP): $24.4 \%$.

The gravimetric humidity of the soil was determined using FAO methodology (Walker, 1989). The water use efficiency (WUE) was determined mathematically as the relationship between the yield of grain obtained and the total water input to the crop (TWI). For the latter, the contribution of irrigation and rainfall throughout the production cycle was considered (Tanner \&
Sinclair, 1983; Neluheni et al., 2007; Reinoso, 2014) and this value was corrected by the factor 0.8 (FAO, 2019). The last irrigation in each treatment was made when the plants reached $100 \%$ of panicle development and began to senesce.

The preliminary tests carried out during the 20102011 and 2011-2012 cycles and the weather data (Figure 1) showed that the low values of precipitation during the establishment of the crop (December) and during most of the cycle did not cover the requirements of the crop (ETc) in the Lower Valley of the Negro river. Therefore, amaranth cultivation requires the application of irrigation for optimal development.

The total water used during the crop growth cycle is shown schematically in table 1. It presents the total water input (TWI) to the soil profile. The sheet of water applied was calculated according to the number of irrigations. The precipitation and evapotranspiration for the study site during the crop cycle were provided by the meteorological station of INTA EEAVI.

\subsection{Biometric parameters}

As described in Zubillaga et al. (2020), during the growth cycle, the following biometric parameters were measured in 10 plants per treatment and for the subplot (for both production cycles, n: 60) : maximum number of leaves (ML), maximum number of nodes $(\mathrm{MN})$ and maximum number of ramifications (MR) with a weekly frequency of seven days. At the end of the growth cycle these selected plants in each treatment were harvested to measure the number of leaves at harvest $(\mathrm{LH})$, ramifications at harvest $(\mathrm{RH})$, foliar area at harvest $(\mathrm{FAH})$, plant height $(\mathrm{PH})$, panicle length (PL) and stem diameter (SD). Thereafter, each plant was dried to constant weight at $60{ }^{\circ} \mathrm{C}$. Leaves (LW), stems (SW), and panicles including grains (PW) were

Table 1. Water management - Gestion de l'eau.

\begin{tabular}{lllll}
\hline & Production cycles & FI & FII & FIII \\
\hline Irrigation number & $2012-2013$ & 12 & 9 & 7 \\
& $2013-2014$ & 13 & 9 & 7 \\
Sheet of water (mm) & $2012-2013$ & 1097 & 823 & 640 \\
& $2013-2014$ & 1189 & 823 & 640 \\
Input of rain (mm) & $2012-2013$ & 122.20 & 122.20 & 122.20 \\
& $2013-2014$ & 121.05 & 121.05 & 112.97 \\
Total water input (TWI) to the soil profile (mm) & $2012-2013$ & 1219.20 & 945.20 & 762.20 \\
& $2013-2014$ & 1310.05 & 944.05 & 752.97 \\
\hline Evapotranspiration (mm) & $2012-2013$ & 701.66 & 683.30 & 672.12 \\
& $2013-2014$ & 702.45 & 679.56 & 669.08 \\
\hline
\end{tabular}

Irrigation frequency: FI, every 7 days; FII, every 14 days; FIII, every 21 days - fréquence d'irrigation : FI, tous les 7 jours ; FII, tous les 14 jours; FIII, tous les 21 jours 
weighed to obtain the total aerial plant biomass (aBW) on a dry basis. Each panicle was threshed by hand and the grains were cleaned with a forced-air current. After that, the number of grains per panicle (NGp), dry weight $(\mathrm{GpW})$ and thousand grain weight (TGW) were recorded for each one. The inflorescence dry weight (IW) was calculated as the difference between the total panicle weight (PW) and the grain weight per panicle (GpW).

The percentage of diseased plants $(\mathrm{Pd})$ with pathogenic fungus Macrophoma sp., at different irrigation treatments, was measured with a weekly frequency in each plot.

The plants of the central furrows were harvested manually to study the biological (BY) and economic (EY) yields and the plant density per ha at harvest time $(\mathrm{DpH})$.

Following Henderson (1993), the phenological stages were recorded chronologically (days after sowing) with a weekly frequency of seven days: plant emergence (E), initiation of panicle development (IP), initiation of anthesis (IA), milky grain (MG), dough grains (DG) and physiological maturity (PM). The growing-degree days (GDD) for the total growth cycle (sowing to physiological maturity) were calculated according to McMaster \& Wilhelm (1997).

The protein content (CP) was determined in the leaves, stems and grains at the time of harvesting by the Kjeldahl method, using factor 5.85 (AOAC, 1990).

The statistical analysis was carried out with InfoStat software (Di Rienzo et al., 2016) as described in Zubillaga et al. (2020). A double ANOVA (years x treatments) was applied to each variable with a randomized block design in each year. The test did not detect any interaction between the years, so the analysis was performed by including all data from both years for each variable and treatment. The mean comparisons were made with Fisher's minimum significant difference (DMS) at $5 \%$.

\section{RESULTS}

\subsection{Evolution of water in the soil}

FI treatment. The day before the scheduled irrigation the gravimetric humidity of the soil was between 25 and $27 \%$ and after $48 \mathrm{~h}$ of irrigation the humidity values reached FC.

FII treatment. From 45 days after sowing when the crop reached the phenology stage of IP, the irrigation frequency was changed from 7 days (first phase) to 14 days (second phase). During the first irrigation phase the soil water was above WP. During the second phase the soil water prior to irrigation reached gravimetric humidity values of $23 \%$ (values lower than $50 \%$ of AWC) on five occasions. After watering, the values of the volumetric moisture reached $\mathrm{FC}$ in measurements made at $48 \mathrm{~h}$.

FIII treatment. From 45 days after sowing, the crops were watered every 7 days (first phase) and then a watering frequency of 21 days (second phase) was applied. During the first phase the gravimetric humidity of the soil on the day prior to irrigation was maintained above WP between 25 and $27 \%$. In the second phase the soil humidity reached values of $20 \%$ of gravimetric humidity (lower values than in the other two treatments). Measurements $48 \mathrm{~h}$ after irrigation showed moisture values in FC which indicated that the applied film was sufficient in all cases, as in the other treatments.

\subsection{Biometric variables}

The variables ML, MR, LH, RH, FAH, PH and LP decreased significantly $(p<0,01)$ as the frequency of irrigation was reduced. Although no differences were detected between the FI and FII frequencies in ML, FAH and PL, the PH was higher in the FII treatment although the differences would not be of agronomic relevance (Table 2 ).

\subsection{Crop yield and its components}

Irrigation frequency significantly affected BY and EY, as shown in table 3 . In most cases the dry weights of the aerial organs of the plants decreased (SW, PW, IW, $\mathrm{LW}$ ), as the frequency of irrigation was reduced.

The EY, GNp and GpW variables showed significant differences $(p<0.01)$ between treatments. These variables reached the maximum values in the FII treatment and the lowest in FIII. TGW did not show any significant differences between the irrigation treatments applied (Table 3).

The BY, DpH and \% Pd showed similar behavior, their values tended to decrease as the frequency of irrigation was reduced. $\mathrm{DpH}$ did not show any statistical differences between the FI and FII treatments, however in FIII a reduction was observed.

\subsection{Water use efficiency and plant diseased}

Regarding the WUE, the values obtained were 2.80; 4.02 and $3.55 \mathrm{~kg} \cdot \mathrm{m}^{-3}$, respectively, for the FI, FII and FIII with statistical differences $(p<0.001)$ between treatments.

The percentage of diseased plants $(\mathrm{Pd})$ with the pathogenic fungus Macrophoma sp. showed differences between treatments $(p<0.001)$ with values of $2.30,1.40$ and $0.79 \%$ for FI, FII and FIII. 
Table 2. Average values of biometric variables at the different irrigation frequencies tested - Valeurs moyennes des variables biométriques aux différentes fréquences d'irrigation testées.

\begin{tabular}{|c|c|c|c|c|}
\hline \multirow[t]{2}{*}{ Variable } & \multicolumn{3}{|c|}{ Irrigation frequency } & \multirow[t]{2}{*}{$p$-value } \\
\hline & FI & FII & FIII & \\
\hline ML (maximum number of leaves) & $32.52^{\mathrm{a}}$ & $32.95^{\mathrm{a}}$ & $30.09^{\mathrm{b}}$ & $<0.01$ \\
\hline MN (maximum number of nodes) & $29.90^{\mathrm{a}}$ & $31.43^{\mathrm{a}}$ & $29.88^{a}$ & $>0.05$ \\
\hline MR (maximum number of ramifications) & $7.30^{\mathrm{a}}$ & $6.70^{\mathrm{b}}$ & $3.40^{c}$ & $<0.01$ \\
\hline LH (number of leaves at harvest) & $23.38^{\mathrm{a}}$ & $22.14^{\mathrm{b}}$ & $18.43^{\mathrm{c}}$ & $<0.01$ \\
\hline RH (ramifications at harvest) & $5.33^{\mathrm{a}}$ & $4.81^{\mathrm{b}}$ & $3.00^{\mathrm{c}}$ & $<0.01$ \\
\hline FAH (foliar area at harvest) $\left(\mathrm{cm}^{2}\right)$ & $1,348.92^{\mathrm{a}}$ & $1,371.85^{\mathrm{a}}$ & $1,208.86^{\mathrm{b}}$ & $<0.01$ \\
\hline PH (plant height $)(\mathrm{cm})$ & $161.43^{\mathrm{b}}$ & $163.02^{\mathrm{a}}$ & $157.95^{c}$ & $<0.01$ \\
\hline PL (panicle length) (cm) & $38.88^{\mathrm{a}}$ & $38.05^{\mathrm{a}}$ & $33.40^{\mathrm{b}}$ & $<0.01$ \\
\hline $\mathrm{SD}($ stem diameter $)(\mathrm{cm})$ & $1.73^{\mathrm{a}}$ & $1.73^{\mathrm{a}}$ & $1.72^{\mathrm{a}}$ & $>0.05$ \\
\hline
\end{tabular}

FI, FII, FIII: see table 1 - voir tableau 1; values of the same variable followed by the same letter are not statistically different by the Fisher LSD test $(p>0.05)$. Each value is the mean of $\mathrm{n}=60$ - les valeurs de la même variable suivies de la même lettre ne sont pas statistiquement différentes par le test Fisher LSD (p >0,05). Chaque valeur est la moyenne de $n=60$.

Table 3. Average values of biological and economic yield and its components at the different irrigation frequencies tested - Valeurs moyennes du rendement biologique et économique et de ses composantes aux différentes fréquences d'irrigation testées.

\begin{tabular}{|c|c|c|c|c|}
\hline \multirow[t]{2}{*}{ Variable } & \multicolumn{3}{|c|}{ Irrigation frequency } & \multirow[t]{2}{*}{$p$-value } \\
\hline & FI & FII & FIII & \\
\hline BY (biological yields) $\left(\mathrm{kg} \cdot \mathrm{ha}^{-1}\right)$ & $24,966.28^{\mathrm{a}}$ & $24,283.56^{b}$ & $18,957.82^{\mathrm{c}}$ & $<0,01$ \\
\hline $\mathrm{DpH}$ (plant density per ha at harvesting time $)\left(\right.$ plants $\left.\cdot \mathrm{ha}^{-1}\right)$ & $160,169.02^{\mathrm{a}}$ & $158,867.48^{\mathrm{a}}$ & $136,826.79^{b}$ & $<0,01$ \\
\hline SW (stem dry weight $)(g)$ & $50.20^{\mathrm{a}}$ & $45.75^{b}$ & $42.81^{\mathrm{c}}$ & $<0,01$ \\
\hline PW (panicle dry weight) $(g)$ & $77.68^{\mathrm{a}}$ & $77.60^{\mathrm{a}}$ & $73.55^{\mathrm{b}}$ & $<0,01$ \\
\hline IW (inflorescence dry weight) $(\mathrm{g})$ & $55.55^{\mathrm{a}}$ & $53.29^{b}$ & $53.73^{b}$ & $<0,05$ \\
\hline LW (leaf dry weight ) $(\mathrm{g})$ & $26.78^{\mathrm{a}}$ & $26.68^{\mathrm{a}}$ & $20.70^{\mathrm{b}}$ & $<0,01$ \\
\hline aBW (aerial-plant-biomass dry weight) & $156.23^{\mathrm{a}}$ & $153.1^{\mathrm{b}}$ & $138.64^{\mathrm{c}}$ & $<0,01$ \\
\hline EY (economic yield) $\left(\mathrm{kg} \cdot \mathrm{ha}^{-1}\right)$ & $3543.48^{b}$ & $3,800.31^{\mathrm{a}}$ & $2,695.55^{\mathrm{c}}$ & $<0,01$ \\
\hline GpW (dry weight of grains per panicle) (g) & $22.13^{b}$ & $24.29^{\mathrm{a}}$ & $19.83^{c}$ & $<0,01$ \\
\hline TGW (thousand kernel weight ) (g) & $0.84^{\mathrm{a}}$ & $0.84^{\mathrm{a}}$ & $0.84^{\mathrm{a}}$ & $>0,05$ \\
\hline GNp (number of grains per panicle ) $(\mathrm{g})$ & $26,369 \cdot 15^{\mathrm{b}}$ & $28,902.16^{\mathrm{a}}$ & $23,651.31^{\mathrm{c}}$ & $<0,01$ \\
\hline
\end{tabular}

FI, FII, FIII: see table 1 - voir tableau 1; values of the same variable followed by the same letter are not statistically different by the Fisher LSD test $(p>0.05)$. Each value is the mean of $\mathrm{n}=60-$ les valeurs de la même variable suivies de la même lettre ne sont pas statistiquement différentes par le test Fisher LSD (p >0,05). Chaque valeur est la moyenne de $n=60$.

\subsection{Phenological stages}

The effects of irrigation frequency on the different phenological stages during the amaranth growth cycle are shown in figure 2 . The total number of days between sowing and physiological maturity showed a tendency to decrease as the frequency of irrigation was reduced with significant statistical differences $(p>0.001)$. The growing cycle was 144 and 136 days for the treatments FI and FII, respectively, and FIII was the treatment that presented the shortest length with 131 days in the crop cycle.The GDD accumulated until maturity showed a tendency to decrease as the irrigation frequency was reduced. Thus, for FI it was 1,708 GDD, for FII, 1,630 GDD and for FIII, 1,620 GDD in a similar sequence to that of days to harvest. 


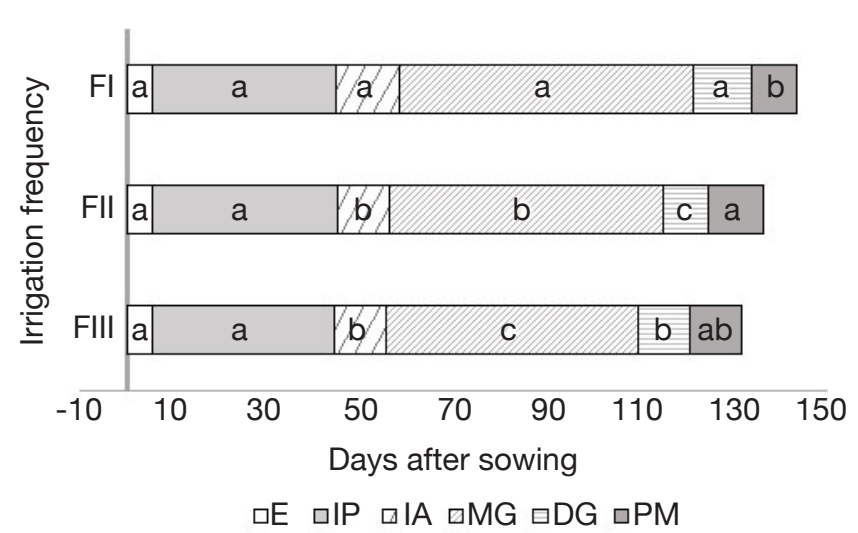

Figure 2. Duration of phenological stages at the different irrigation frequencies - Durée des stades phénologiques aux différentes fréquences d'irrigation.

FI, FII, FIII: see table 1 - voir tableau 1; values of the same variable followed by the same letter are not statistically different by the Fisher LSD test $(p>0.05)$ - les valeurs de la même variable suivies de la même lettre ne sont pas statistiquement différentes par le test Fisher LSD ( $\mathrm{p}>0,05)$; E: emergence - émergence; IP: initiation of panicle development - initiation du développement de la panicule; IA: initiation of anthesis - initiation de l'anthèse; MG: milky grain - grain laiteux; DG: dough grains - grains de pâte; PM: physiological maturity - maturité physiologique.

\subsection{Crude protein concentration}

The percentage of crude protein concentration in the plant stems, leaves, and grains tended to increase as the irrigation frequency was reduced (Figure 3). However, no statistical differences were found in grain and leaf between the II and III frequencies.

\section{DISCUSSION}

\subsection{Irrigation}

Plants have evolved in response to drought through morphological, anatomical and physiological adaptations that have allowed them to grow and develop in different degrees of water scarcity, even under conditions of constant deficit (Moreno \& Liz, 2009). In general, when the water needs of a crop are not met, this deficit can cause an adverse effect on crop growth and yield (Igbadun \& Oyebode, 2000).

The irrigation treatments used in this study resulted in sheets of water of similar values for the complete crop cycle in each year (Table 1). The only difference was that the FI treatment of the 2013-2014 cycle received one more application of irrigation than the cycle 2012-2013. The contribution of precipitation was higher in the 2012-2013 cycle, although the differences were not significant compared with 2013-2014. This

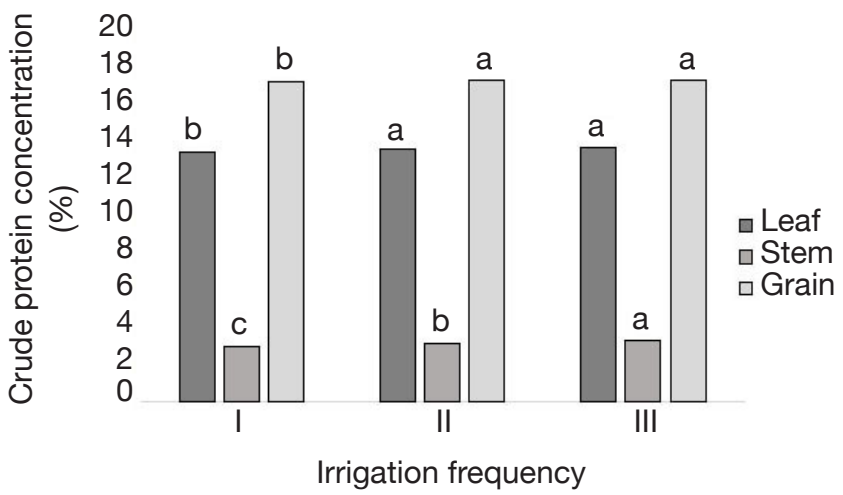

Figure 3. Crude protein concentration (\%) of stems, leaves and grains in amaranth plants grown at the different irrigation frequencies - Concentration en protéines brutes (\%) des tiges, des feuilles et des grains dans les plantes d'amarante cultivées aux différentes fréquences d'irrigation.

FI, FII, FIII: see table 1 - voir tableau 1; values of the same variable followed by the same letter are not statistically different by the Fisher LSD test $(p>0.05)$ - les valeurs de la même variable suivies de la même lettre ne sont pas statistiquement différentes par le test Fisher LSD ( $\mathrm{p}>0,05)$.

greater contribution of water by precipitation resulted in a reduction of the differences in TWI between the FI treatments of the different cycles, although it increased them in the other treatments. However, the differences for this variable between treatments never exceeded $10 \%$. It is important to highlight that the amount of irrigation water applied in the FI treatment compared to FII was approximately $300 \mathrm{~mm}$ higher, and approximately $500 \mathrm{~mm}$ higher compared to FIII.

\subsection{Evolution of water in the soil}

All the trials were irrigated weekly in the first phase of treatments, which probably favored the root development in the top centimeters of the soil. When the second phase of treatments was applied in FII and FIII, changing the dynamics of water in the soil, the roots probably developed to a greater depth in order to extract water from substrates of deeper soil, as observed by Reinoso (2014) for the same study area. Other authors mention, for this species, that root growth is accelerated during the drought period, being identified as an adaptive mechanism that provides an active demand for water. Root penetration at greater depth allows obtaining moisture from deeper horizons (Valdayskikh et al., 2019).

\subsection{Biometric variables}

The behavior observed in ML and LH would explain the lower FAH values found in FIII (Table 2). In the 
case of LH, differences were found between FI and FII, however the magnitude of these did not manifest in the FAH values. In this sense several authors indicated that a decrease in the leaf area is considered an adaptive strategy of species that are tolerant to water stress, although in some cases development can be recovered quickly once the stress conditions end (Moreno \& Liz, 2009).

The MN variable did not show any differences $(p<0.05)$ between the different treatments, possibly because it is a characteristic of the cultivar that is not affected by water stress. Nonetheless, PH showed a tendency to decrease in FIII and it could be assumed that it would be the elongation of the internodes that is affected by the availability of water. Stem diameter did not show any variation associated with the irrigation treatments, although reductions in this variable have been observed with the increase in the degree of stress produced (Masariramb et al., 2012).

\subsection{Crop yield and its components}

The observed decrease in BY with the reduction of irrigation frequency (Table 3) could be due to the fact that, in most cases (SW, PW, IW, LW), the dry weights of the aerial organs of the plants decreased and this explains the reduction in aBW. Although in the case of LW and PW variables, significant differences were detected with respect to FIII, but not between FI and FII. Similar results were published by Kwizera et al. (2018) in amaranths where intermediate rates of irrigation resulted in the highest leaf area, number of leaves and yields.

The reduction observed in $\mathrm{LH}$ would explain the lower LW values obtained, a variable that in turn affected the behavior of aBW and consequently the BY. With this biomass reduction the luminous interception and photosynthate production decreased which was reflected in the grain yield. These results are consistent with that found by other authors regarding reductions in height, number of leaves, leaf area, biomass and yield of those plants with treatments in which the application of water was reduced (Neluheni et al., 2007; Masariramb et al., 2012; Chauhan \& Abugho, 2013).

In relation to $\mathrm{aBW}$ and its components (SW, PW and LW), they all showed a reduction in FIII. The aBW component that contributed most to this variable was PW (represented by GpW and IW) with percentages close to 50\%, while SW and LW represent $30 \%$ and $20 \%$, respectively (Table 3). However, PW the main representative of aBW did not show any significant differences between FI and FII, a behavior that agrees with that observed in PL.

Considering the behavior of PW previously reported and that TGW did not show any differences between the irrigation treatments, it is assumed that it was its components ( $\mathrm{GpW}$ and $\mathrm{GNp}$ ) that showed differences in favor of the FII treatment. This fact allows us to suppose that FI compensates the PW through IW (variable of greater value in FI) and suggests that FII makes the crop more efficient, given that lower volumes of water produced higher $\mathrm{GpW}$ and GNp and consequently higher values of EY. A possible explanation for this could be that the flowers in the FII treatment had fewer abortions. This fact agrees with the explanation proposed by Oury et al. (2016) that, under moderate water stress, the plants coordinate the decrease of the expansive growth rate and the flow of photosynthates. This fact requires an early determination of the abortion of the seeds in order to establish the flow of carbon to the rest of the ovules. On the other hand, Bancal (2008) found that water stress causes a decrease in yield because the plant translocates its reserves early, with the consequent imbalance in metabolism during grain filling.

The behavior of the variable aBW was reflected in BY where, by reducing the frequency of irrigation, the values of this variable were also decreased. This response would be related to the decrease observed in the different aBW components as the period between irrigation applications is extended.

In relation to plant growth during the first stages of plant development, the water in the soil plays an important role in the vegetative development of the crop that will later influence the yield. Although the response of this crop to severe stress conditions is not known, from the grain filling stage the amaranth responds to moderate stress conditions with an increase in root development that allows it to extract water at greater depths (Johnson \& Henderson, 2002). In these experiments all the irrigation frequencies evaluated provided an adequate volume of water in soil during the first stages of development of the crop. The lower contribution of water supplied in the FII treatment, from the beginning of the IP stage, only had slight effects on plant development. In this sense it is important to emphasize that the formation of the inflorescence was not affected, which resulted in higher EY and BY values than in the FI treatment. On the other hand, in the FIII treatment, the plants were exposed to more severe drought conditions which affected the morpho-physiological development of the plant and the formation of the inflorescence that was reflected in negative effects on EY. Mlakar et al. (2012) in an experimental trial with A.cruentus G6 in a greenhouse showed that inflorescence formation is a critical growing stage which influences grain yield. The literature mentions yield reductions of $19 \%$ when water deficit occurs at flowering and $9 \%$ at grain formation (Ayodele, 2000). In this experiment, the drought stress generated (FIII) showed a $24 \%$ reduction in yield, 
which was due to the fact that the stress period included both stages (flowering and grain filling), observing an additive effect.

\subsection{Water use efficiency and plant diseased}

In FI the application of more water $(1,264 \mathrm{~mm})$ caused a small but significant increase in yields $\left(3,543 \mathrm{~kg} \cdot \mathrm{ha}^{-1}\right)$ which generated a lower WUE (2.80). Similar results were reported by Neluheni et al. (2007). In accordance with the results of this study other studies had found that the WUE increases in conditions of water deficit, as observed in the cultivation of soybean with moderate deficit of water in the soil during the vegetative stage, as well as in corn and sunflower (Turk \& Hall, 1980; Green \& Read, 1983)

Likewise, another study recommended irrigation that resulted in maintaining the soil in conditions below field capacity, although not lower than $40 \%$, since the yields and the general development of the crop would be seriously affected by water stress (Masariramb et al., 2012). On the contrary, Ogunlela \& Sadiku (2017) found that maximum WUE did not correspond to the maximum yield in amaranth.

Respect to the percentage of diseased plants (Pd) with the pathogenic fungus Macrophoma sp. the increase of irrigation frequency favored the conditions necessary for the development of the fungus, affecting the crop productivity. Some authors confirmed that humidity explains the abundance of fungi (Talley et al., 2002). Lower irrigation frequencies, such as FIII, could be a management strategy in Macrophoma amaranth susceptible cultivars.

\subsection{Phenological stages}

Regarding the duration of phenological stages (Figure 2), similar behavior was observed between treatments for E and IP stages. From 40 to 45 days after sowing at the IA stage, differences between irrigation frequencies began to be observed. However, the greatest variation in days between treatments was manifested between IA and MG and it was maintained until the crop was mature.

In relation to the phenology of the crop, shortening of the total crop cycle was observed by decreasing the frequency of irrigation. This reduction was seen from the anthesis stage and was more noticeable in the phenological stage between IA and MG. This effect is possibly associated with the lower volumes of water received, as well as the water status of the soil throughout the cycle. In FIII, unlike the other treatments, the soil reached values near to WP twice in the two years of study. These drought events occurred during the stages of anthesis and grain filling which are the times of greatest sensitivity of the crop. This fact possibly explains the loss of plants and the reduction in yield observed. The difference between FI and FIII was 12 days, and 90 days for GDD. Some authors (Ayodele, 2000; Fasinmirin et al., 2009; Mlakar et al., 2012) described that the time of flowering can be affected by low water availability, however, a moderate drought promoted increased values of leaf area, biomass and grain yield (Olufolaji et al., 2010). In this case, and from the anthesis stage, the amaranth tolerated moderate drought conditions which could be explained by a greater development of roots (Johnson \& Henderson, 2002). Leaf fall (reduced LW) minimises transpiration area and photosynthetic surface area; however, the leaves that fell were those in the lower canopy and/or senescent, so these effects were probably not significant. Pulvento et al. (2015) suggested that the use of complementary irrigation during phenological phases of amaranth that are more sensitive to drought could cause the crop to maintain a higher seed yield.

Plants have two main response mechanisms to water deficit, tolerance and avoidance or escape (Kramer, 1983; Valladares et al., 2004). Among the tolerant plants are those in which dehydration is reduced through complex morpho-physiological mechanisms such as: small and waxy leaves, structures that facilitate the uptake of dew, deep roots (phreatophyte plants), reduction in the number and size of stomata, modification of the structure of the canopy, anatomical changes in the epidermis, location of the stomata in cavities, thick and waxy cuticles in combination with succulent tissues, or CAM metabolisms. Avoidance is understood as the use of cycles of very rapid growth or early maturity, which allows rapid use of water availability to avoid periods of drought (Kramer, 1983; Valladares et al., 2004). This latter mechanism could be associated with the shortening of the cycle or early maturity observed in FIII. Similarly, the reduction observed in LH, RH and FAH could be associated with tolerance mechanisms in this species, although more research would be required.

The results found in this study are consistent with those of Fasinmirin et al. (2009) where A.cruentus reached the maturity stage early due to the effect of drought stress produced at the sensitive stage, between vegetative and flowering (50-57 days after the sowing). Similar trials for the same species indicated that flowering is the most sensitive stage to drought (Ayodele, 2000; Mlakar et al., 2012). This suggests for the climatic condition of valleys of Northeast Patagonia an optimal management of irrigation of 7 days for the establishment of the crop (stage of initiation of panicle development) and then a frequency of 14 days until the beginning of the stage of dough grain. This management of irrigation generated an adequate plant stand at panicle initiation and allows a proper 
development of plant with optimal biological and economical yields and the highest efficiency of water use $\left(4.02 \mathrm{~kg} \cdot \mathrm{m}^{-3}\right)$. This study confirms that amaranth could be grown through sustainable irrigation management to avoid high yield losses in future climate scenarios. Moreover, it would contribute to improve food security with the possibility of mitigating the adverse effects of climate change (Alemayehu et al., 2015; Pulvento et al., 2015).

\subsection{Crude protein concentration}

The percentage of crude protein concentration in the plant stems, leaves, and grains tended to increase as the irrigation frequency was reduced. These results in leaves and stems could be associated with a morphophysiological response of the plant which decreases its structural carbohydrates and increases soluble carbohydrates to maintain an osmotic adjustment that allows its survival. This is a strategy that allows the amaranth plant to continue its functions even in severe drought conditions (Liu \& Stützel, 2002; Omami \& Hammes, 2010). Under drought conditions the overall size of the plant biomass and the size of stems and leaves are reduced. This response could be related to increased stomatal closure which would decrease the photosynthetic rate (Taiz \& Zeiger, 2006) and cause disturbances in the normal functioning of amino acid and carbohydrate metabolism, for example, carbohydrate and protein metabolite accumulation in the leaves (Lawlor \& Cornic, 2002) which could explain the results obtained. In agreement with the results of Lavini et al. (2016), the chemical composition of amaranth seeds was affected by irrigation treatments with an increase in protein due to the effect of drought.

\section{CONCLUSIONS}

This report represents the most southern study on irrigation frequency with respect to phenology, yield and water use efficiency in the amaranth crop.

The number of days between sowing and maturity increased with irrigation frequency.

The results obtained in these trials show that an irrigation management of 7 days for crop establishment and then with a frequency of 14 days induces a lower incidence of diseases, the highest economic yield and the best water use efficiency. This management allows a more efficient use of water resources and less prone conditions for the development of fungal diseases (Macrophoma sp.) without significant plant loss.

Future experiments will be carried out to study the response of new species and different soil textures characteristic of Northern Patagonia to rational water management. Furthermore, the effect of drought on the expression of proteins and secondary metabolites will be evaluated.

\section{Abbreviations}

aBW: aerial plant biomass dry weight

AWC: available water content

BY: biological yield

CP: protein content

DG: dough grains

DpH: plant density per ha at harvest time

E: plant emergence

ETc: crop evapotranspiration

ETo: reference evapotranspiration

EY: economic yields

FAH: foliar area at harvest

FC: field capacity

FI: irrigation every 7 days

FII: irrigation every 14 days

FIII: irrigation every 21 days

GDD: growing-degree days

GNp: number of grains per panicle

GpW: dry weight of grains per panicle

IA: initiation of anthesis

IP: initiation of panicle development

IW: inflorescence dry weight

Kc: crop coefficients

LH: number of leaves at harvest

LW: leaves dry weight

MG: milky grain

ML: maximum number of leaves

MN: maximum number of nodes

MR: maximum number of ramifications

Pd: diseased plants

PH: plant height

PL: panicle length

PM: physiological maturity

PW: panicle dry weight

RH: ramifications at harvest

SD: stem diameter

SW: stems dry weight

TGW: thousand grain weight

TWI: total water input

WP: permanent wilting point

WUE: water use efficiency

\section{Acknowledgements}

The authors would like to thank the following institutions: UNRN, UNS, INTA and CONICET for their support in this study.

\section{Bibliography}

Alemayehu F.R., Bendevis M.A. \& Jacobsen S.E., 2015. The potential for utilizing the seed crop amaranth 
(Amaranthus spp.) in East Africa as an alternative crop to support food security and climate change mitigation. J. Agron. Crop Sci., 201(5), 321-329, doi.org/10.1111/ jac. 12108

A.O.A.C. (Association of Official Analytical Chemists), 1990. Official methods of analysis. $15^{\text {th }}$ ed. Washington: A.O.A.C.

Ayodele V.I., 2000. Influence of soil water stress at different physiological stages on growth and seed yield of Amaranthus species. Acta Hortic., 537, 767-772, doi. org/10.17660/actahortic.2000.537.91

Bancal P., 2008. Positive contribution of stem growth to grain number per spike in wheat. Field Crops Res., 105, 27-39, doi.org/10.1016/j.fcr.2007.06.008

Barba de la Rosa A.P., Silva-Sanchez C. \& Gonzalez de Mejia E., 2007. Amaranth: an ancient crop for modern technology. In: Tunick M.H. \& Gonzalez De Mejia E., eds. Hispanic foods: chemistry and flavor. Washington : American Chemical Society, 103-116.

Brommer J.M. \& Morgenstern G., 1992. Backeigenschaften der Pseudo-Cerealien Amaranth und Quinua. Getreide Mehl Bot., 46(3), 78-84.

Cassini P. \& La Rocca F., 2014. Amaranthus cruentus L. is suitable for cultivation in central Italy: field evaluation and response to plant densities. Ital. J. Agron., 9(4), 166175.

Chauhan B.S. \& Abugho S.B., 2013. Effects of water regime, nitrogen fertilization, and rice plant density on growth and reproduction of lowly weed Echinochloa crus-galli. Crop Prot., 54, 142-147.

Correa A.D., Jokl L. \& Carlsson R., 1986. Amino acid composition of some Amaranthus sp. grain proteins and of its fractions. Arch. Latinoam. Nutr., 3, 466-476.

Di Rienzo J.A. et al., 2016. InfoStat versión 2008. Grupo InfoStat,FCA. Cordoba, Argentina: Universidad Nacional de Córdoba, http//www infostat.com.ar, (19/10/2021).

FAO, 2019. CropWat, www.fao.org/land-water/databasesand-software/cropwat/es/, (February 2019).

Fasinmirin J.T., Olufayo A.A., Oguntunde P.G. \& Oguntuase A.M., 2009. Parametrizing simple model between yield and evapotranspiration for Amaranthus cruentus under drip and sprinkler irrigations. Int.J. Plant Prod., 3(1), 75-90.

Fuentes Yagúe J.L., 1998. Técnicas de Riego. $3^{\text {rd }}$ ed. Madrid: Ed. Mundi Prensa.

Green D.G. \& Read D.W.L., 1983. Water use efficiency of corn, sunflower and wheat with limiting soil moisture. Can. J. Plant Sci., 63(3), 747-749.

Henderson T.L., 1993. Agronomic evaluation of grain amaranth in North Dakota. Phd thesis: North Dakota State University, Fargo (USA).

Hoidal N., Díaz Gallardo M., Jacobsen S.E. \& Alandia G., 2019. Amaranth as a dual-use crop for leafy greens and seeds: stable responses to leaf harvest across genotypes and environments. Front. Plant Sci., 10, 817, doi. org/10.3389/fpls.2019.00817
Igbadun H.E. \& Oyebode M.A., 2000. Effect of delayed irrigation at critical growth stage on yield of wheat. Savannah J. Agric. Mech., 2(1), 63-64.

Jacobsen S.E. \& Mujica A., 2003. The genetic resources of Andean grain amaranths (Amaranthus caudatus L., A.cruentus L. and A. hipochondriacus L.) in America. Plant Genet. Resour. Newsl., 133, 4144.

Johnson B.L. \& Henderson T.L., 2002. Water use patterns of grain amaranth in the northern great plains. Agron.J., 94, 1437-1443, doi.org/10.2134/agronj2002.1437

Kauffman C.S. \& Weber L.E., 1990. Grain amaranth. In: Janick J. \& Simon J.E., eds. Advances in new crops. Portland, USA: Timber Press, 127-139.

Klute A., 1986. Water retention: laboratory methods. In: Klute A., ed. Methods of soil analysis. Part 1. $2^{\text {nd }}$ ed. Madison, WI, USA: American Society of Agronomy \& Soil Science Society of America, 635-661.

Kramer P.J., 1983. Drought tolerance and water efficiency. In: Water relations of plants. New York, NY, USA: Academy Press, 390-415.

Kwizera Ch. et al., 2018. Effects of different irrigation rates on growth and yield parameters of amaranth. Int. J. Adv. Sci. Res. Eng., 4(9), 93-99, doi.org/10.31695/ ijasre.2018.32870

Lavini A. et al., 2016. Effects of saline irrigation on yield by qualitative characterization of seed of an amaranth accession grown under Mediterranean conditions. J. Agric. Sci., 154(5), 858-869, doi.org/10.1017/ s0021859615000659

Lawlor D.W. \& Cornic G., 2002. Photosynthetic carbon assimilation and associated metabolism in relation to water deficits in higher plants. Plant Cell Environ., 25, 275-294.

Liu F. \& Stützel H., 2002. Leaf water relations of vegetable amaranth (Amaranthus spp.) in response to soil drying. Eur. J. Agron., 16, 137-150, doi.org/10.1016/s11610301(01)00122-8

Liu F.L. \& Stützel H., 2004. Biomass partitioning, specific leaf area, and water use efficiency of vegetable amaranth (Amaranthus spp.) in response to waterstress.Sci.Hortic., 102, 15-27, doi.org/10.1016/j.scienta.2003.11.014

Martínez R.S., Margiotta F., Reinoso L. \& Martínez R.M., 2012. Buscando alcanzar altos rendimientos del cultivo de maíz: experiencias en los valles Norpatagónicos. In: Proceedings of the $3^{\text {ra }}$ Reunión Internacional de Riego, October 30-31, 2012, INTA Manfredi, Córdoba, Argentina.

Masariramb M.T. et al., 2012. Soil water requirements of amaranth (Amaranthus hybridus) grown in a greenhouse in a semi-arid, sub-tropical environment. Am.-Eurasian J. Agric. Environ. Sci., 12(7), 932-936.

McMaster G.S. \& Wilhelm W.W., 1997. Growing degreedays: one equation, two interpretations. Agric. For. Meteorol., 87, 291-300, doi.org/10.1016/s01681923(97)00027-0 
Mlakar S.G., Bavec M., Jakop M. \& Bavec F., 2012. The effect of drought occurring at different growth stages on productivity of grain amaranth Amaranthus cruentus G6. J. Life Sci., 6(3), 283-286.

Moreno F. \& Liz P., 2009. Respuesta de las plantas al estrés por déficit hídrico. Una revisión. Agron. Colomb., 27(2), 179-191.

Neluheni K., Du Plooy C.P. \& Mayaba N., 2007. Yield response of leafy amaranths to different irrigation regimes. In: Proceedings of the $8^{\text {th }}$ African Crop Science Conference, October 27-31, El-Minia, Egypt, 16191623.

Ogunlela A.O. \& Sadiku I.B., 2017. Yield and water use efficiency of Amaranthus cruentus grown under smsbased irrigation system. J. Res. For. Wildl. Environ., 9(3), 47-57.

Olufolaji A.O., Odeleye F.O. \& Ojo O.D., 2010. Effect of soil moisture stress on the emergence, establishment and productivity of amaranthus (Amaranthus cruentus L.). Agric. Biol.J.N.Am., 1(6), 1169-1181.

Omami E.N. \& Hammes P.S., 2006. Interactive effects of salinity and water stress on growth, leaf water relations, and gas exchange in amaranth (Amaranthus spp.). N.Z. J. Crop Hortic. Sci., 34, 33-34, doi.org/10.1080/011406 71.2006 .9514385

Oury V. et al., 2016. Is change in ovary carbon status a cause or a consequence of maize ovary abortion in water deficit during flowering? Plant Physiol., 171, 997-1008.

Pulvento C. et al., 2015. Assessing amaranth adaptability in a Mediterranean area of South Italy under different climatic scenarios. Irrig. Drain., 64, 50-58, doi. org/10.1002/ird.1906

Reinaudi N.B. et al., 2011. Evaluación de genotipos de amaranto (Amaranthus spp.) para la adaptabilidad productiva en el área de la Facultad de Agronomía. Rev. Cient. UDO Agríc., 11(1), 50-57.

Reinoso L.G., 2014. Rendimeinto de maíz en el valle inferior de Rio Negro. Evaluacion de las frecuecia de riego y la fertilización nitrogenada. Phd thesis: Universidad Nacional del Sur, Bahia Blanca (Argentina).

Richards L.A., 1947. Pressure-membrane apparatusconstruction and use. Agric. Eng., 28, 451-454.

Robert Y.N., Hiroe K. \& Yotaro K., 2008. Antioxidant activity of various extracts and fractions of Chenopodium quinoa and Amaranthus spp. seeds: analytical, nutritional and clinical methods. Food Chem., 106, 760-766, doi. org/10.1016/j.foodchem.2007.06.004

Solanki R.P. et al., 2016. Effect of scheduling irrigation and organic manure on yield attributes, nutrient content and uptake of rabi Amaranthus (Amaranthus paniculatus L.) in Saurashtra region. Int. J. Sci. Environ. Technol., 4(5), 2076-2083.
Taiz L. \& Zeiger E., 2006. Plant physiology. $4^{\text {th }}$ ed. Sunderland, MA, USA: Sinauer Associates, Inc.

Talley S.M., Coley P.D. \& Kursar T.A., 2002. The effects of weather on fungal abundance and richness among 25 communities in the Intermountain West. BMC Ecol., 2, 7.

Tanner C.B. \& Sinclair T.R., 1983. Efficient water use in crop production: research or re-search. In: Taylor H.M. et al., eds. Limitations to efficient water use in crop production. Madison, WI, USA : American Society of Agronomy, 1-27.

Turk K.J. \& Hall A.E., 1980. Drought adaptation of cowpea III. Influence of drought on plant growth and relation with seed yield. Agron. J., 72, 428-433.

Ufoegbune G.C., Adebiyi G.A. \& Adekunle A.A., 2016. Determination of water use of three vegetables; Amaranthus (Amaranthus cruenthus), Jutemallo (Corchorus olitorius) and Celosia (Celosia argentea) at Abeokuta, Nigeria. J. Environ. Anal. Toxicol., 6(3), doi. org/10.4172/2161-0525.1000374

Valdayskikh V.V., $\quad$ Voronin P.Y., Artemyeva E.P. \& Rymar V.P., 2019. Amaranth responses to experimental soil drought. In: AIP Conference Proceedings, Vol.2063, No. 1, 030023. AIP Publishing LLC.

Valladares F. et al., 2004. Capítulo 6 estrés hídrico: ecofisiología y escalas de la sequía en ecología del bosque mediterráneo en un mundo cambiante. Madrid: Ministerio de Medio Ambiente, EGRAF S.A., 163-190.

Venskutonis P.R. \& Kraujalis P., 2013. Nutritional components of amaranth seeds and vegetables: a review on composition, properties, and uses. Compr. Rev. Food Sci. Food Saf., 12(4), 381-412.

Walker W.R., 1989. Guidelines for designing and evaluating surface irrigation systems. FAO Irrigation and Drainage Paper 45. Roma: FAO.

Zubillaga M.F., 2017. Comportamiento del cultivo de amaranto en el valle inferior del Río Negro, Argentina. Optimización de las condiciones del cultivo. $\mathrm{PhD}$ thesis : Universidad Nacional del Sur, Bahía Blanca (Argentina).

Zubillaga M.F., Camina R., Orioli G.A. \& Barrio D.A., 2019. Response of Amaranthus cruentus cv Mexicano to nitrogen fertilization under irrigation in the temperate, semiarid climate of North Patagonia, Argentina. J. Plant Nutr., 42(2), 99-110, doi.org/10.1080/01904167.2018.1 549674

Zubillaga M.F. et al., 2020. Amaranth in southernmost latitudes: plant density under irrigation in Patagonia, Argentina. Rev. Ceres Viçosa, 67(2), 93-99, doi. org/10.1590/0034-737x202067020001

(55 ref.) 